\title{
Using quantitative real-time polymerase chain reaction (qRT-PCR) for detection microcystin producing cyanobacteria
}

\author{
Thanh-Luu Pham ${ }^{1,2,}{ }^{*}$, Tran Thi Hoang Yen ${ }^{1}$, Tran Thanh Thai ${ }^{1}$, Ngo Xuan Quang ${ }^{1,2}$
}

${ }^{1}$ Institute of Tropical Biology, Vietnam Academy of Science and Technology (VAST), 85 Tran Quoc Toan Street, District 3, Ho Chi Minh City, Vietnam

${ }^{2}$ Graduate University of Science and Technology, Vietnam Academy of Science and Technology, 18 Hoang Quoc Viet Street, Hanoi 100000, Viet Nam

\section{Correspondence}

Thanh-Luu Pham, Institute of Tropical Biology, Vietnam Academy of Science and Technology (VAST), 85 Tran Quoc Toan Street, District 3, Ho Chi Minh City, Vietnam

Graduate University of Science and Technology, Vietnam Academy of Science and Technology, 18 Hoang Quoc Viet Street, Hanoi 100000, Viet Nam

Email: thanhluupham@gmail.com

History

- Received: 2021-02-23

- Accepted: 2021-05-05

- Published: 2021-05-13

DOI : 10.32508/stdj.v24i2.2523

\section{Check for updates}

\section{Copyright}

(๑) VNU-HCM Press. This is an openaccess article distributed under the terms of the Creative Commons Attribution 4.0 International license.

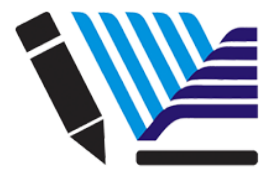

VNU-HCM Press

\begin{abstract}
Introduction: Cyanobacterial blooms (CBs) have become a growing concern worldwide. In the natural environment, potentially toxic (can produce toxins) and non-toxic (can not produce toxins) colonies often co-exist within a bloom. Methods: The present study aimed to quantify toxic and non-toxic cells of cyanobacteria in the Tri An Reservoir (TAR) using a quantitative real-time polymerase chain reaction (qRT-PCR). Results: Results showed that the Microcystis genus dominated the cyanobacterial communities in the TAR. Microcystis was also the primary microcystins (MC) producing cyanobacteria in the water. Total cyanobacteria and Microcystis cells ranged from $152 \times 10^{3}$ to $27 \times 10^{6} \mathrm{copy} / \mathrm{L}$ and from $105 \times 10^{3}$ to $19 \times 10^{6}$ copy/L, respectively. The cell number of potentially MC-producing cyanobacteria (corresponding to the Microcystis mcyD gene) varied from $27 \times 10^{3}$ to $13 \times 10^{6}$ copy/L. MC concentrations often present in raw water with a concentration up to $4.8 \mu \mathrm{g} / \mathrm{L}$. Our results showed that the MC concentration in raw water was positively correlated with the mcyD copy number, suggesting that Microcystis spp. are the main toxin producers in the TAR's surface water. Conclusion: Our study suggested that qRT-PCR techniques and traditional count are comparable and could be used to quantify cyanobacteria. In addition, the qRT-PCR techniques can determine the toxic cyanobacterial cells and could be used as a tool for early monitoring of toxic cyanobacteria in lakes and reservoirs.

Key words: cyanotoxins, microcystins, toxic and non-toxic cyanobacteria, Tri An Reservoir
\end{abstract}

\section{INTRODUCTION}

Toxic cyanobacterial blooms (TCBs) in inland lakes and reservoirs have become a worldwide problem ${ }^{1}$. These blooms have resulted in economic loss due to degradation of water quality and increase health risk $^{2}$. Furthermore, TCBs are responsible for several toxic secondary metabolites, namely cyanotoxins, including cyclic peptides, alkaloids, and lipopolysaccharides based on chemical structure. Microcystins (MC), a group of cyclic heptapeptide hepatotoxins, are the most frequently occurring even in eutrophic freshwaers ${ }^{3}$. The thiotemplate mechanism characteristic synthesizes MC for non-ribosomal peptide synthesis (NRPS), polyketide synthesis (PKS), and fatty acid synthesis in the MC biosynthesis gene cluster $(m c y)$, which spans $55 \mathrm{~kb}$ and composes of 10 genes structured in two putative operons $(m c y A-C$ and $m c y D-J)^{4}$. Producing by the toxic cells of different cyanobacteria, including Microcystis, Dolichospermum, and Planktothrix, MC is the largest diverse group of cyanobacterial toxins more than 100 variants reported $^{5}$. TCBs with the dominant of Microcystis and MC have been reported worldwide ${ }^{6}$.

Microcystins are intracellular toxin and can be released when blooms collapse or as cells die, result- ing in the contamination of MC in water, sediments and in different aquatic organisms ${ }^{1,3}$. Because a natural population of cyanobacteria community or a cyanobacterial bloom often consists of two genotypes toxic (can produce toxins) and non-toxic (can not produce toxins) strains, the differentiation of the two genotypes is difficult due to the similar appearance under microscope $e^{7,8}$. Therefore, the discovery of the $m c y$ gene cluster has given a potential way for PCR-based detection of MC producers. However, although the conventional PCR could detect the presence or absence of the $m c y$ genes in cyanobacteria, it could not quantify the potentially toxic and nontoxic cell number. Therefore, the quantitative realtime PCR (qRT-PCR) techniques based on the detection of the $m c y$ genes that only exist in the potentially toxic cells have recently been used for quantification the cell number of toxic and non-toxic within a sample ${ }^{9,10}$.

Located in Southern Vietnam, the Tri An Reservoir (TAR) is one of Vietnam's most important water sources. It provides drinking water for more than 10 million people from Ho Chi Minh City, Dong Nai, and Binh Duong provinces ${ }^{11}$. The occurrence of toxic cyanobacterial bloom in the TAR has been 
reported during the most ten years. In some case, MC have been found with concentration exceeding the World Health Organization (WHO) provisional guideline concentration of $1.0 \mu \mathrm{g} / \mathrm{L}^{12-14}$. However, previous studies have focused only on the taxonomic identification of cyanobacterial population or detection of MC concentration in the water. No study contributed to the quantification of the toxic cells within a population. To better understand the variation of cyanobacterial blooms and the toxin production, easy-to-use detection methods for different toxin-producing cyanobacteria are needed. Thus, this study aimed to apply qRT-PCR techniques to quantify toxic and non-toxic Microcystis colonies in the water.

\section{MATERIALS AND METHODS}

\section{Samples collection}

Surface water samples (2L) were collected monthly in a 2L plastic bottle from the TAR in 2017 at one station (Figure 1) and transported to the laboratory with ice. Sub-samples were fixed with Lugol's iodine solution for cell count using a Sedgewick Rafter counting chamber. Cyanobacterial cells in raw water were concentrated by filtering $100 \mathrm{~mL}$ through GF/C filters (Whatman, Kent, England). Samples on the filter were divided for DNA extraction and MC measurement. For DNA extraction, the filters were kept at $20^{\circ} \mathrm{C}$ before further process. For MC analysis, the filters were dried overnight at $45^{\circ} \mathrm{C}$ and held at $-20^{\circ} \mathrm{C}$ before analysis.

\section{Microcystins extraction and measurement}

MC's content in filters samples was extracted with $100 \%$ methanol and measured using a highperformance liquid chromatography (HPLC) (Dionex UltiMate 3000, Thermo Scientific, Waltham, MA, USA). The HPLC system is equipped with a reverse-phase C18 column (Acclaim ${ }^{M} 120 \mathrm{C} 185 \mu \mathrm{m}$, $4.6 \times 150 \mathrm{~mm}$, Waltham, MA, USA), an autosampler, and a UV-VIS detector. A buffer including methanol and $0.05 \mathrm{M}$ phosphate solution $(\mathrm{pH} 2.5 ; 1: 1 \mathrm{v} / \mathrm{v})$ at a flow rate of $0.65 \mathrm{~mL} / \mathrm{min}$ was used as mobile phase. The systems were maintained at $40^{\circ} \mathrm{C}$ during analysis. Three MC congeners, including (MC-RR, MC-LR, and MC-YR) were distinguished by UV at $238 \mathrm{~nm}$ and identified based on retention time and UV spectra. Three MC variants, including MC-LR, MC-RR, and MC-YR from Enzo Lifesciences (Farmingdale, NY, USA) were used as standards. The HPLC system had a detection limit of $0.1 \mu \mathrm{g} / \mathrm{L}$.

\section{DNA extraction and qRT-PCR standard} preparation

The frozen GF/C filters were used for DNA extraction. First, cyanobacterial DNA was extracted using the GeneAll $^{R}$ Exgene $^{\mathrm{TM}}$ Cell SV kit (GeneAll, Seoul, Korea), following the manufacturer's instructions. After extraction, the DNA was purified with the purification kit (Omega Biotek, GA, USA) and quantified with a spectrometer (Eppendorf D30, Hamburg, Germany) to obtain the DNA concentration. The final DNA yields were preserved in a $20 \mu \mathrm{L}$ TE buffer (10 $\mathrm{mM}$ Tris-HCl, $1 \mathrm{mM}$ EDTA, $\mathrm{pH}$ 8.0) and kept at $20^{\circ} \mathrm{C}$ before further analysis.

To prepare qRT-PCR standards, the DNA extracted from the two strains, including a toxic Microcystis aeruginosa NIES-102 and a non-toxic $M$. aeruginosa NIES-101 (NIES, Tsukuba, Japan) with a serial dilution from $1.0 \times 10^{2}$ to $1.0 \times 10^{7}$ were used. In our study, we aim to quantify three genes, including the cyanobacterial 16S rRNA (responsible for total cyanobacteria cells), the Microcystis 16S rRNA (responsible for total Microcystis cells), and Microcystis mcyD (responsible for a total of Microcystis cells with the ability to produce MC). These genes were amplified by using the primers listed in Table 1 . The PCR products were collected and purified with the DNA purification kit (Omega Biotek, GA, USA). DNA was then quantified with a spectrophotometer. The copy number of each gene was calculated based on the Avogadro's number $\left(1 \mathrm{~mol}=6.02214 \times 10^{23}\right.$ molecules) ${ }^{8,15}$.

\section{Quantitative real-time polymerase reaction}

Total cyanobacteria cells, total Microcystis spp. and total toxic Microcystis spp. were quantified by using the cyanobacterial 16S rRNA, Microcystis $16 \mathrm{~S}$ rRNA, and Microcystis $m c y D$, respectively. qRT-PCR assay was performed according to the process described by Nübel et al. (1997) ${ }^{16}$ and Baxa et al. (2010) ${ }^{15}$. Accordingly, all qRT-PCR reactions were run in triplicate with a total of $20 \mu \mathrm{L}$ that contained $10 \mu \mathrm{L}$ of SYBR green master mix (Toyobo, Japan), $0.2 \mu \mathrm{L}$ (10 $\mathrm{pmol} / \mu \mathrm{L}$ ) of each forward and reverse primers, $1 \mu \mathrm{L}$ of DNA template, and MQ water. The reaction was run on a Real-time PCR PikoReal system (Thermo Scientific, MA, USA). The thermal profile of the qRT-PCR reaction was followed from Nübel et al. (1997) ${ }^{16}$ and Baxa et al. (2010) ${ }^{15}$. For cyanobacterial $16 \mathrm{~S}$ rRNA the thermal protocol of qRT-PCR was performed as follows: $95^{\circ} \mathrm{C}$ for $5 \mathrm{~min}, 45$ cycles at $95^{\circ} \mathrm{C}$ for $15 \mathrm{~s}$, $60^{\circ} \mathrm{C}$ for $15 \mathrm{~s}$ and $72{ }^{\circ} \mathrm{C}$ for $30 \mathrm{~s}$. The thermal protocol 


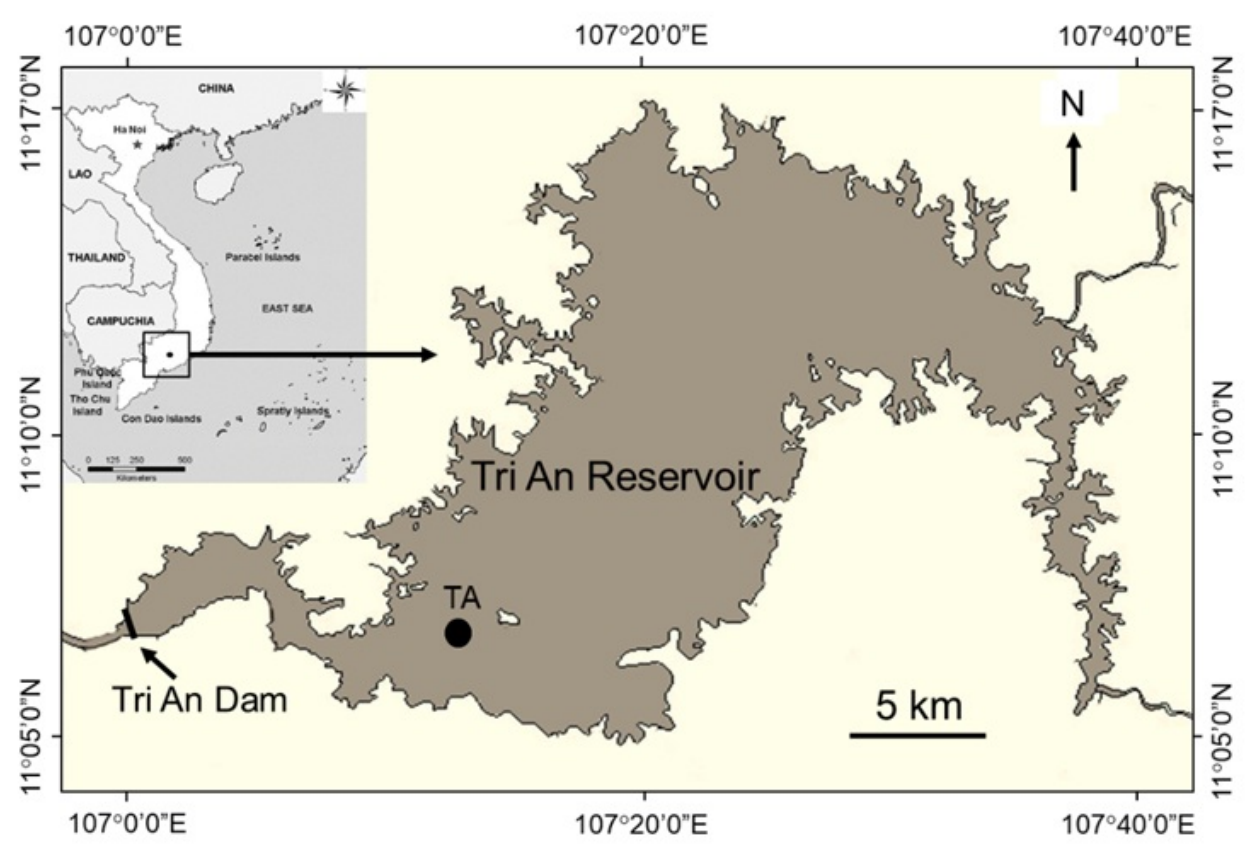

Figure 1: Map of the Tri An Reservoir with sampling location (TA).

Table 1: Primers used for qPCR

\begin{tabular}{lllll}
\hline Target & Primer & Sequence $\left(5^{\prime}-3^{\prime}\right)$ & $\begin{array}{l}\text { Size } \\
(\mathrm{bp})\end{array}$ & Reference \\
$\begin{array}{l}\text { Cyanobacterial } \\
\text { 16S rRNA }\end{array}$ & Cya 359F & GGGGAATYTTCCGCAATGGG & 446 & Nübel et al. (1997) $)^{16}$ \\
& Cya 781R & GACTACWGGGGTATCTAATCCCWTT & & \\
$\begin{array}{l}\text { Microcystis } \\
\text { 16S rRNA }\end{array}$ & Micr 184F & GCCGCRAGGTGAAAMCTAA & 220 & \\
& Micr 431R & AATCCAAARACCTTCCTCCC & & \\
$\begin{array}{l}\text { Microcystis } \\
\text { mcyD }\end{array}$ & mcyD F2 F & GGTTCGCCTGGTCAAAGTAA & 298 & Baxa et al. $(2010)^{15}$ \\
& & & & \\
\hline
\end{tabular}

for Microcystis $16 \mathrm{~S}$ rRNA and Microcystis $m c y D$ was run as follow: initial at $50{ }^{\circ} \mathrm{C}$ for $3 \mathrm{~min}$, then $95^{\circ} \mathrm{C}$ for $10 \mathrm{~min}$, followed by 45 cycles at $95^{\circ} \mathrm{C}$ for $30 \mathrm{~s}, 61^{\circ} \mathrm{C}$ for $1 \mathrm{~min}$, and finally at $72^{\circ} \mathrm{C}$ for $20 \mathrm{~s}$.

\section{RESULTS}

\section{Cyanobacterial cell count and microcystins} in water

The monthly cyanobacteria cells, total Microcystis cells, and MC concentration in surface water were shown in Figure 2. Total cyanobacteria cell count ranged from $144 \times 10^{3}$ to $26 \times 10^{6}$ cell/L, with a peak in July, in which the total Microcystis cells ranged from $100 \times 10^{3}$ to $23.6 \times 10^{6}$ cell/L (accounting for 68-91\%). MC was detected from March to November, with the concentration ranged from under detection limit (UDL) to $4.8 \mu \mathrm{g} / \mathrm{L}$, with a peak in June. The maximum concentrations of cyanobacteria, $\mathrm{Mi}$ crocystis, and MC concentrations were measured in June and July as the occurrence of heavy blooms of M. aeruginosa on surface water (Figure 3). 


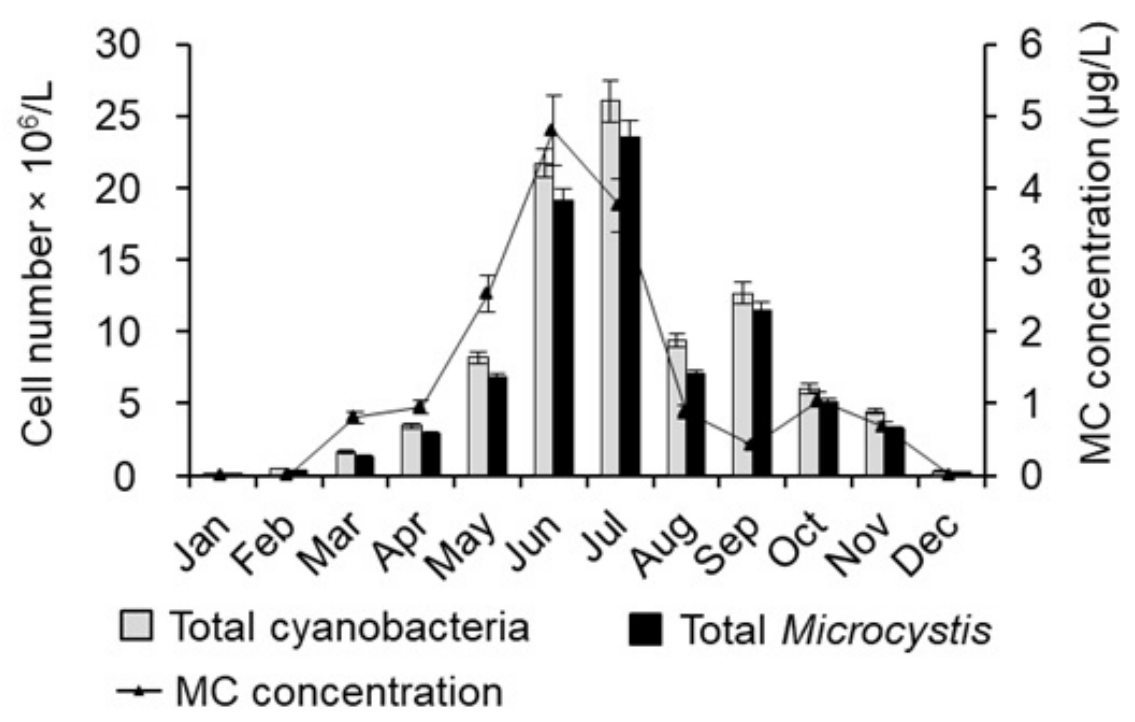

Figure 2: Cell number of cyanobacteria, Microcystis and MC concentration
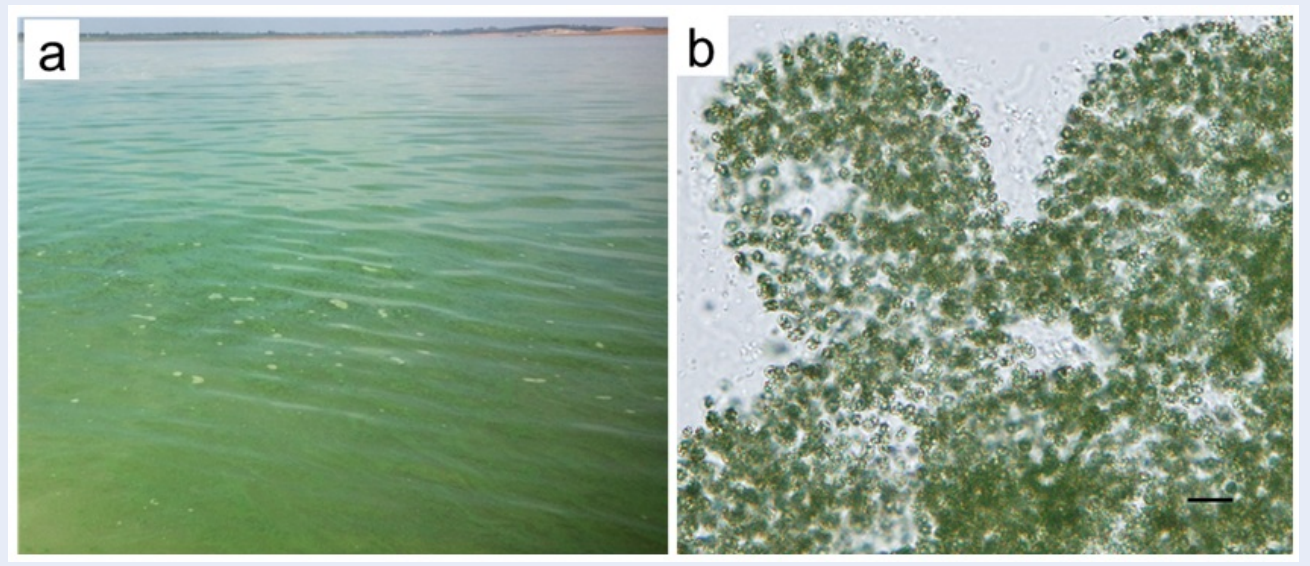

Figure 3: Surface bloom of cyanobacteria (a) with the dominant Microcystis aeruginosa (b) in the Tri An Reservoir. Scale bar: $10 \mu \mathrm{m}$.

\section{Quantitative analysis of cyanobacteria by qPCR}

We first run the standard curves using the DNA extracted from the toxic $M$. aeruginosa NIES-102, then applied for the samples collected from the TAR. Our results showed that all three genes (cyanobacterial $16 \mathrm{~S}$ rRNA gene, Microcystis 16S rRNA gene, and the Microcystis mcyD gene) generated good efficiencies and high R-square value. In addition, sAnd significant linear curves between the concentration of DNA and the threshold cycle values $(\mathrm{Ct})$ were obtained for all genes (Figure 4 and Table 2). Table 2 showed the efficiencies and other parameters obtained for different standard curves. The efficiencies of the qRT-PCR assays ranged from 0.997 to 1.050 , demonstrating the high reliability of the qRT-PCR amplification.

The mean copy number of cyanobacterial 16S rRNA, Microcystis $16 \mathrm{~S}$ rRNA, and Microcystis mcyD as determined by qRT-PCR were shown in Figure 5. Our results indicated that the copy number of the cyanobacterial 16S rRNA and Microcystis 16S rRNA showed almost the same trend and ranged from $152 \times 10^{3}$ to $27 \times 10^{6} \mathrm{copy} / \mathrm{L}$ and from $105 \times 10^{3}$ to $19 \times 10^{6} \mathrm{copy} / \mathrm{L}$, respectively. They gradually increased from Mar and 

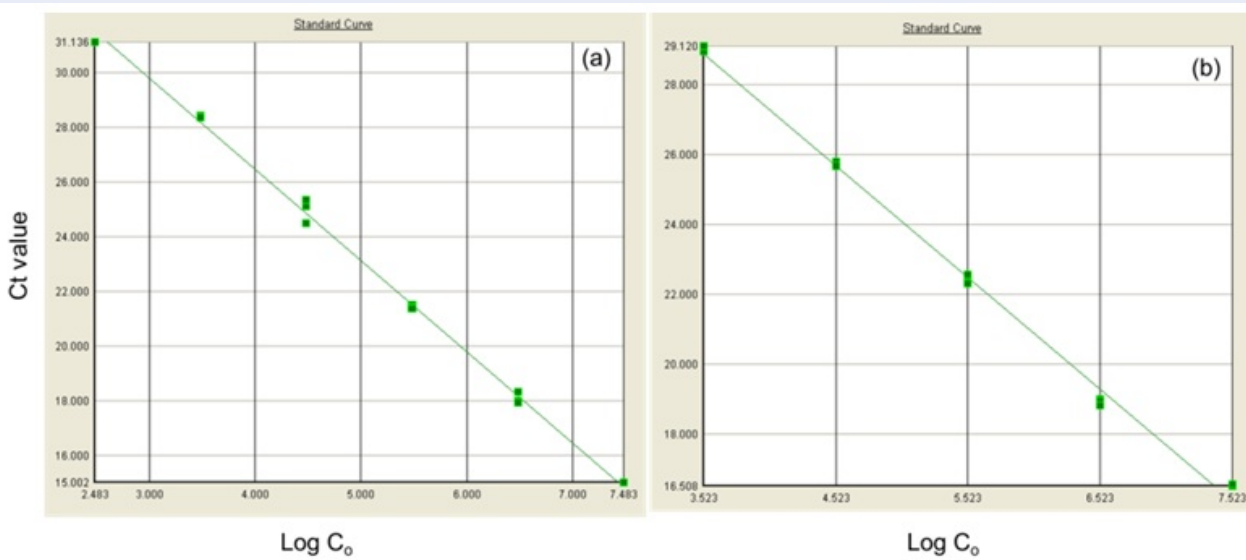

Figure 4: Standard curves of the cyanobacterial 16S rRNA (a) and Microcystis 16S rRNA (b).

Table 2: The efficiencies and other standard curve parameters were obtained by real-time qPCR analysis for (a) the cyanobacterial $16 \mathrm{~S}$ rRNA and (b) the Microcystis $16 \mathrm{~S}$ rRNA specific primer sets. The amplification efficiency (e) was calculated by $e=10^{-1 / S}-1$, where $S$ is the slope.

\begin{tabular}{lllccc}
\hline Target gene & Standard & Efficiency & Slope & Y-intercept & R2 \\
$\begin{array}{l}\text { Cyanobacterial } \\
\text { 16S rRNA }\end{array}$ & M. aeruginosa NIES-102 DNA & 1.007 & -3.305 & 44.328 & 0.995 \\
$\begin{array}{l}\text { Microcystis } \\
\text { 16S rRNA }\end{array}$ & M. aeruginosa NIES-102 DNA & 1.050 & -3.208 & 40.167 & 0.996 \\
Microcystis mcyD & M. aeruginosa NIES-102 DNA & 0.997 & -3.33 & 40.683 & 0.993 \\
\hline
\end{tabular}

often got peaks during Jun or Jul and remained at high values to October before declining during December to April. The Microcystis 16S rRNA gene was dominant, accounting for $60.3-91.7 \%$ of the total cyanobacteria abundance. The number of the $M i-$ crocystis $m c y D$ gene corresponding to the number of cells with the ability to produce MC) changed similarly with the cyanobacterial $16 \mathrm{~S}$ rRNA and Microcystis $16 \mathrm{~S}$ rRNA genes. It got the maximum value in June $\left(13 \times 10^{6}\right.$ copy/L) and the minimum value in January $\left(27 \times 10^{3} \mathrm{copy} / \mathrm{L}\right)$. The proportion of potentially MC-producing cyanobacteria varied from $16.0 \%$ to 95.7\%, with the highest value recorded in October and the lowest value recorded in March. Our results confirmed this method could be applied to detect cyanobacteria in environmental samples with a wide range of cyanobacterial abundance (from $1.0 \times 10^{2}$ to $1.0 \times 10^{7}$ cells/L).

The ratio of Cyanobacteria 16S rRNA/total cyanobacteria and Microcystis 16s rRNA/total Microcystis as determined by qRT-PCR and traditional count were shown in Table 3. Both the ratio range from 0.811.18 , and in most cases, these numbers higher than 1 , suggesting that the number of cells is determined by
qRT-PCR is a little higher than the traditional count. However, both methods are comparable and could be used as optional tools for cyanobacteria quantification. The qRT-PCR methods could be quantified the toxic cell number of cyanobacteria while the other could not.

\section{DISCUSSION}

In natural environments, toxic and non-toxic genotypes are often found within a bloom ${ }^{17}$. Globally, $20-75 \%$ of cyanobacterial bloom cases reported being toxic ${ }^{3}$. In most cases the Microcystis spp. blooms have been reported the bloom-forming and toxin producer $^{6}$. The bloom of Microcystis spp. with toxin production has been reported in many lakes and reservoirs, including Lake Thanh Cong, Hoan Kiem Lake, Huong River, and Dau Tieng Reservoir, Tri An Reservoir, Tuyen Lam Reservoir. However, earlier reports have not yet employed molecular techniques $^{12,14,18}$. Especially, the qRT-PCR technique has not been used to quantify the toxic and nontoxic cyanobacteria from Vietnam's water. The traditional count is the common methods used to quantify the total cyanobacteria number but did not quantify 


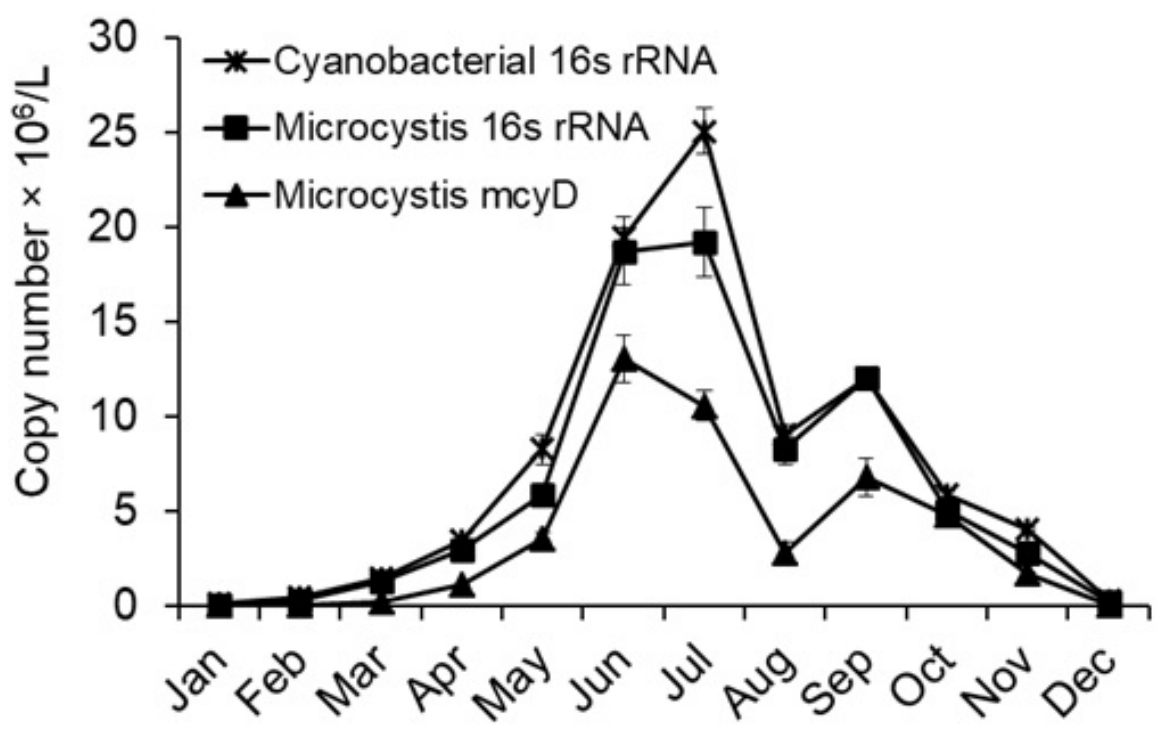

Figure 5: Mean copy number of cyanobacterial 16S rRNA, Microcystis $16 \mathrm{~S}$ rRNA, and Microcystis mcyD as determined by qRT-PCR.

Table 3: The ratio of Cyanobacteria 16S rRNA/Total cyanobacteria and Microcystis 16s rRNA/Total Microcystis as determined by qRT-PCR and traditional count

\begin{tabular}{lccccccccccccc}
\hline & Jan & Feb & Mar & Apr & May & Jun & Jul & Aug & Sep & Oct & Nov & Dec \\
& & 1.06 & 1.04 & 0.91 & 1.00 & 1.01 & 1.04 & 1.04 & 1.04 & 1.14 & 1.16 & 1.05 & 0.94 \\
$\begin{array}{l}\text { Cyano 16S rRNA/Total } \\
\text { cyanobacteria }\end{array}$ & & & & & & & & & & & & & \\
$\begin{array}{l}\text { Micro 16s rRNA/Total } \\
\text { Microcystis }\end{array}$ & 1.03 & 1.00 & 1.05 & 1.04 & 0.86 & 0.98 & 0.81 & 1.18 & 1.04 & 0.97 & 0.86 & 1.08 \\
\hline
\end{tabular}

the number of the toxic cell of cyanobacteria. Thus, in the present study, we have successfully applied a qRT-PCR technique to quantify different cyanobacterial groups based on molecular approaches. The qRT-PCR could be used for the determination of total cyanobacteria or different toxic genotypes with a population. When applied qRT-PCR for monitoring the dynamics of cyanobacteria and MC production in a tropical reservoir of Singapore, Te and Gin (2011) ${ }^{19}$ reported that Microcystis and Anabaena were present (mean concentrations $4.16 \times 10^{6}$ gene copies $/ \mathrm{mL}$ and $4.47 \times 10^{4}$ gene copies $/ \mathrm{mL}$, respectively) and were well correlated to each other $(P<0.001)$, and that $M i$ crocystis was the primary microcystin producer. The average percentage of toxigenic Microcystis spp. was $55.92 \%$, whereas no Anabaena-specific microcystinproducing gene was detected. Our results are consistent with previous observations that the proportion of potentially toxic Microcystis genotypes in different water locations can vary widely. In some cases, the potentially toxic Microcystis genotypes reached $100 \%{ }^{15}$. We suggested to use these techniques for future monitoring of cyanobacteria as well as cyanotoxins in Vietnam waters.

Many studies have documented the contamination of MC in Vietnam's surface waters ${ }^{4,7,12,18}$. However, the variation of toxin producers has not been investigated to the same extent. In this study, MC was detected in almost all tested samples, including those of raw water and water blooms. In comparison, we determined the variation of toxic Microcystis via the mcyD copy number. Our results showed that the MC concentration in raw water was positive correlated with the $m c y D$ copy number $(\mathrm{R}=0.87)$, suggesting that Microcystis spp. are the primary toxin producer in the surface water of the TAR. This confirmed again the toxic genotypes are linking with $\mathrm{MC}$ concentration in a natural population. Furthermore, our results were consistent with previous reports that Microcystis spp. was the bloomforming species and toxin producer in Vietnam waters $7,17,18,20$. 
The present study showed the MC concentration was often present in raw water. Based on the results, the MC concentration in the surface water sample was up to $4.8 \mu \mathrm{g} / \mathrm{L}$. This concentration was higher than the concentration reported in the Nui Co reservoir but lower than the number reported in Hoan Kiem Lake and other locations in Southern Vietnam ${ }^{18,20}$. However, these concentrations sometimes exceeded the WHO guideline value of $1 \mu \mathrm{g} / \mathrm{L}$ for MC in drinking water toxic ${ }^{3}$. The treated water may be contaminated with MC due to the water treatment plants having no facilities for removing $\mathrm{MC}$ from drinking water, nor is monitoring being conducted to detect MC in drinking water. Therefore, during periods of high Microcystis spp. in the reservoir, local people may suffer toxic effects via daily exposure to the contaminated water. It is necessary to establish a regularly monitoring program for cyanobacteria and cyanotoxins in lakes and reservoirs used for drinking purposes. In addition, the detection of other cyanotoxins such as anatoxins, saxitoxins, and cylindrospermopsins from the TAR is highly recommended.

\section{CONCLUSIONS}

In the present study, a qRT-PCR technique was successfully applied to quantify the potential of MC production in different cyanobacterial genotypes from the TAR. Our results indicated that Microcystis main produced MC. The concentration of Microcystis spp. contributed from $60-92 \%$ of the total cyanobacterial population. Our results indicated that the qRT-PCR techniques and traditional count are comparable and could be used to quantify cyanobacteria. In addition, the qRT-PCR techniques can determine the toxic cell number with a population. They could be used for early monitoring of toxic cyanobacteria in lakes and reservoirs.

\section{LIST OF ABBREVIATIONS}

CBs: Cyanobacterial blooms

Ct: cycle values

HPLC: high performance liquid chromatography

MC: micocystins

NRPS: non-ribosomal peptide synthesis

PKS: polyketide synthesis

qRT-PCR: quantitative real-time polymerase chain reaction

TAR: Tri An Reservoir

TCBs: Toxic cyanobacterial blooms

UDL: under detection limit

WHO: World Health Organization

\section{COMPETING INTERESTS}

The authors declare that they have no conflicts of interest.

\section{AUTHORS' CONTRIBUTIONS}

Pham Thanh Luu carried out the sample collections, analyses, interpretation of data, and writing the manuscript. Tran Thi Hoang Yen carried out the sample collections, analyzed and counted cyanobacteria. Tran Thanh Thai carried out the sample collections. Ngo Xuan Quang supported data analyses and revising the manuscript.

\section{ACKNOWLEDGMENTS}

This research was funded by the Vietnam Academy of Science and Technology (VAST) under grant number "KHCBSS.02/19-21".

\section{REFERENCES}

1. Pham TL, Utsumi M. An overview of the accumulation of microcystins in aquatic ecosystems. Journal of Environmental Management. 2018; 213: 520-529;PMID: 29472035. Available from: https://doi.org/10.1016/j.jenvman.2018.01.077.

2. Huo S, He Z, Ma C, Zhang H, Xi B, Xia X, Xu Y, Wu F. Stricter nutrient criteria are required to mitigate the impact of climate change on harmful cyanobacterial blooms. Journal of Hydrology. 2019; 569: 698-704;Available from: https://doi.org/10. 1016/j.jhydrol.2018.12.030.

3. Chorus I, Bartram J. Toxic cyanobacteria in water: A guide to their public health consequences, monitoring and management. Published on behalf of WHO, Spon Press, London. 1999;p. 416. Available from: https://doi.org/10.1201/ 9781482295061

4. Kurmayer R, Christiansen $G$. The genetic basis of toxin production in cyanobacteria. Freshwater Reviews. 2009; 2: 31 50;Available from: https://doi.org/10.1608/FRJ-2.1.2.

5. Pham TL, Dao TS, Tran ND, Nimptsch J, Wiegand C, Motoo U. Influence of environmental factors on cyanobacterial biomass and microcystin concentration in the Dau Tieng Reservoir, a tropical eutrophic water body in Vietnam. Annales de Limnologie - International Journal of Limnology. 2017; 53: 89100;Available from: https://doi.org/10.1051/limn/2016038.

6. Harke MJ, Steffen MM, Gobler CJ, Otten TG, Wilhelm SW, Wood SA, Paerl HW. A review of the global ecology, genomics, and biogeography of the toxic cyanobacterium, Microcystis spp.. Harmful Algae. 2016; 54: 4-20;PMID: 28073480. Available from: https://doi.org/10.1016/j.hal.2015.12.007.

7. Pham TL, Dao TS, Shimizu K, Lan-Chi DH, Utsumi M. Isolation and characterization of microcystin-producing cyanobacteria from Dau Tieng Reservoir, Vietnam. Nova Hedwigia. 2015; 10(1-2): 3-20;Available from: https://doi.org/10.1127/nova hedwigia/2014/0243.

8. Rinta-Kanto JM, Ouellette AJ, Boyer GL, Twiss MR, Bridgeman TB, Wilhelm SW. Quantification of toxic Microcystis spp. during the 2003 and 2004 blooms in western Lake Erie using quantitative real-time PCR. Environmental Science \& Technology. 2005; 39(11): 4198-4205;PMID: 15984800 . Available from: https://doi.org/10.1021/es048249u.

9. Singh S, Rai PK., Chau R, Ravi AK, Neilan BA, Asthana RK. Temporal variations in microcystin-producing cells and microcystin concentrations in two fresh water ponds. Water Research. 2015; 69(Supplement C): 131-142;PMID: 25463934 Available from: https://doi.org/10.1016/j.watres.2014.11.015. 
10. Lehman PW, Kurobe T, Lesmeister S, Baxa D, Tung A, Teh SJ. Impacts of the 2014 severe drought on the Microcystis bloom in San Francisco Estuary. Harmful Algae. 2017; 63: 94108;PMID: 28366405. Available from: https://doi.org/10.1016/ j.hal.2017.01.011.

11. Erik H. Megalopolitan megalomania: Ho Chi Minh City, Vietnam's Southeastern region and the speculative growth machine. International Planning Studies. 2019; 24(1): 5367;Available from: https://doi.org/10.1080/13563475.2018. 1533453.

12. Dao TS, Nimptsch J, Wiegand C. Dynamics of cyanobacteria and cyanobacterial toxins and their correlation with environmental parameters in Tri An Reservoir, Vietnam. Journal of Water Health. 2016; 14: 669-712;PMID: 27441865. Available from: https://doi.org/10.2166/wh.2016.257.

13. Nguyen $\mathrm{HQ}, \mathrm{Ha} \mathrm{NT}$, Pham TL. Inland harmful cyanobacterial bloom prediction in the eutrophic Tri An Reservoir using satellite band ratio and machine learning approaches. Environmental Science and Pollution Research. 2020; 27: 91359151;PMID: 31916153. Available from: https://doi.org/10. 1007/s11356-019-07519-3.

14. Pham TL. Toxins and secondary metabolites from cyanobacteria. Natural Sciences and Technology Publisher, Ha Noi. 2020;p. 207.

15. Baxa DV, Kurobe T, Ger KA, Lehman PW, Teh SJ. Estimating the abundance of toxic Microcystis in the San Francisco Estuary using quantitative real-time PCR. Harmful Algae. 2010; 9(3): 342-349;Available from: https://doi.org/10.1016/j.hal.2010.01. 001.

16. Nübel U, Garcia-Pichel F, Muyzer G. PCR primers to amplify $16 \mathrm{~S}$ rRNA genes from cyanobacteria. Applied and Environmental Microbiology. 1997; 63(8): 3327-3332;PMID: 9251225. Available from: https://doi.org/10.1128/AEM.63.8.3327-3332.1997.

17. Pham TL. Water temperature and nutrients boost Microcystis blooms and microcystin production in a drinking water reservoir, Vietnam. Fundamental and Applied Limnology. 2019; 192(4): 293-303;Available from: https://doi.org/10.1127/fal/ 2019/1167.

18. Duong $T$, Jähnichen $S$, Le $T$, Ho $C$, Hoang $T$, Nguyen $T$, $\mathrm{Vu} \mathrm{T}$, Dang $\mathrm{D}$. The occurrence of cyanobacteria and microcystins in the Hoan Kiem Lake and the Nui Coc reservoir (North Vietnam). Environmental Earth Sciences. 2014; 71(5): 2419-2427;Available from: https://doi.org/10.1007/ s12665-013-2642-2.

19. Te SH, Gin KYH. The dynamics of cyanobacteria and microcystin production in a tropical reservoir of Singapore. Harmful Algae. 2011; 10(3): 319-329;Available from: https://doi.org/10. 1016/j.hal.2010.11.006.

20. Bui BT, Dao TS, Faassen E, Lürling M. Cyanobacterial blooms and microcystins in Southern Vietnam. Toxins (Basel). 2018; 10(11): 471-491;PMID: 30441825 . Available from: https://doi. org/10.3390/toxins10110471. 